\title{
REVIEW
}

\section{Fixed-Dose Combinations for Treatment of Type 2 Diabetes Mellitus}

\author{
Lawrence Blonde · Zinnia T. San Juan
}

To view enhanced content go to www.advancesintherapy.com

Received: November 1, 2011 / Published online: January 16, 2012

(C) The Author(s) 2012. This article is published with open access at Springerlink.com

\section{ABSTRACT}

Introduction: Combining antihyperglycemic agents with complementary mechanisms of action is a cornerstone of type 2 diabetes mellitus (T2DM) management. Although several fixed-dose combinations (FDCs) are available, representing standard types of combination therapy in T2DM, use of these products has been limited. Methods: To address the likely concerns of prescribers and patients regarding the use of FDCs in the treatment of T2DM, literature searches were

Lawrence Blonde $(\varangle)$

Department of Endocrinology, Diabetes and Metabolic Diseases, Ochsner Medical Center, 1514 Jefferson Highway, New Orleans, LA, 70121, USA.

Email: lblonde@ochsner.org

Zinnia T. San Juan

Department of Internal Medicine, Division of Endocrinology, Texas Tech University Health Sciences Center, El Paso, TX, USA

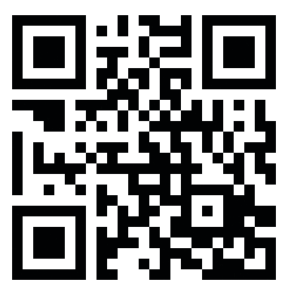

Enhanced content for Advances in Therapy articles is available on the journal web site: www.advancesintherapy.com performed to ascertain the bioavailability, efficacy, tolerability, and cost-effectiveness of the currently approved FDCs compared with their individual component drugs given as separate pills in combination. Additionally, data were collected on rates of adherence, clinical outcomes, and overall treatment costs with FDCs versus dual therapy with the same constituent drugs. Results: Bioavailability is equivalent for FDCs and dual therapy used in T2DM. Efficacy and tolerability also appear to be at least as good with FDCs as with dual therapy. Retrospective analyses have suggested that FDCs can enhance adherence to therapy, presumably as a result of the reduction in pill burden, and improved adherence may result in improved glycemic control and reduced disease management costs. In addition, because currently available FDCs come in two or more dose-strength formulations, they also afford some measure of dosing flexibility. Conclusions: The available evidence supports the wider use of FDCs in the treatment of patients with T2DM.

Keywords: adherence; bioavailability; cost; efficacy; FDC; fixed-dose combination; glycemic control; tolerability; type 2 diabetes mellitus 


\section{INTRODUCTION}

For more than a decade, fixed-dose combinations (FDCs) of orally administered drugs have been available for the treatment of numerous disorders, including HIV, tuberculosis, hypertension, and type 2 diabetes mellitus (T2DM). These pills consist of two or more pharmaceutical compounds in a single tablet. Whereas agents used to treat infectious diseases, such as tuberculosis, are combined primarily to capitalize on synergistic effects to prevent or overcome drug resistance, ${ }^{1}$ the usual purpose of combinations for other conditions is to employ complementary mechanisms of action to address different aspects of the disease pathophysiology. For example, in T2DM, an insulin sensitizer (metformin or a thiazolidinedione [TZD]) may be combined with an insulin secretagogue (a sulfonylurea or a meglitinide) or an incretin-based agent (a glucagon-like peptide-1 [GLP-1] receptor agonist or a dipeptidyl peptidase-4 [DPP-4] inhibitor).

The FDCs approved for treatment of T2DM in the USA (as well as the names of FDCs also available in Europe) are listed in Table 1. For most of these FDCs, bioavailability of each component drug is equivalent to that seen when coadministered as separate pills, as demonstrated for regulatory approval. ${ }^{2-9}$ With metformin/ glyburide, bioavailability of metformin is equivalent to that seen when coadministered with glyburide as separate pills; however, the area under the plasma concentration versus time curve for glyburide is higher than that seen when coadministered with metformin as separate pills. ${ }^{10}$

Despite the advantages FDCs can offer, their use has been relatively modest. This paper examines the use of FDCs versus separatepill combination therapy with the same drugs for the treatment of T2DM and assesses the evidence that may address some of the concerns of prescribers, payers, and patients.

\section{METHODS}

A literature search was conducted on PubMed using the search string "fixed-dose combination" or "single-pill combination" AND "type 2 diabetes" in the title and/or abstract fields. This initial search yielded approximately 80 citations. Although the majority of these citations were primary reports, many of them were studies comparing FDCs versus monotherapy with one of the component drugs, rather than FDCs versus dual therapy with both of the component drugs, which is the focus of this review. The authors also performed supplementary searches on the trade names of each of the currently available FDCs used in T2DM and on the equivalent combinations of generic names. Preference was given to prospective and retrospective primary sources that provided data on the factors considered most likely to affect prescribers' and patients' perceptions and concerns about the use of FDCs versus dual therapy: bioavailability, efficacy, safety, tolerability, glycemic control and other clinical outcomes, adherence to treatment, and costs. Also, when deemed appropriate, the authors have cited reports on the use of FDCs in clinical areas other than T2DM, previous reviews that revealed important general principles of combination therapy with FDCs versus dual therapy, and product label information for the FDCs currently available for treatment of T2DM.

\section{COMBINATION THERAPY IN T2DM}

T2DM results from multiple pathophysiologic defects, including insulin resistance, impaired insulin secretion, and impairment in the incretin 
system. Insulin resistance develops in the liver, contributing to elevated hepatic gluconeogenesis, and also in muscle and fat, where it limits glucose uptake by these tissues. Impaired insulin secretion results primarily from progressive beta-cell dysfunction and loss of beta-cell mass. Incretin impairment in T2DM involves a deficiency in GLP-1 and decreased sensitivity to the insulinstimulatory effects of both GLP-1 and glucosedependent insulinotropic polypeptide (GIP). ${ }^{11}$

Table 1. Available fixed-dose combinations (FDCs) by class and mechanism of action (continued on next page).

\begin{tabular}{|c|c|c|c|}
\hline Class (targets*) & $\begin{array}{l}\text { US trade name(s) } \\
\text { (generic components: dose }[\mathrm{mg}] \text {; } \\
\text { frequency) }\end{array}$ & $\begin{array}{l}\text { Available in Europe } \\
\text { as: }\end{array}$ & Mechanisms of action \\
\hline $\begin{array}{l}\text { Metformin }+ \\
\text { sulfonylurea } \\
(\mathrm{A}, \mathrm{B})\end{array}$ & $\begin{array}{l}\text { Glucovance }{ }^{\star} \text { (Bristol-Myers } \\
\text { Squibb, NJ, USA) } \\
\text { (glyburide/metformin IR: } \\
\text { 1.25/250, 2.5/500, 5/500; twice } \\
\text { daily) } \\
\text { Metaglip (Bristol-Myers Squibb, } \\
\text { NJ, USA) } \\
\text { (glipizide/metformin IR: } 2.5 / 250 \text {, } \\
\text { 2.5/500, 5/500; twice daily) }\end{array}$ & - & $\begin{array}{l}\text { Metformin } \\
\text { - Improves hepatic insulin } \\
\text { sensitivity and reduces hepatic } \\
\text { gluconeogenesis } \\
\text { - May improve peripheral } \\
\text { insulin sensitivity and increase } \\
\text { glucose uptake in muscle } \\
\text { Sulfonylurea } \\
\text { - Increases insulin secretion } \\
\text { from pancreatic beta-cells }\end{array}$ \\
\hline $\begin{array}{l}\text { Metformin }+ \\
\text { meglitinide } \\
(\mathrm{A}, \mathrm{B})\end{array}$ & $\begin{array}{l}\text { Prandimet }^{\circ} \text { (Novo Nordisk, } \\
\text { Bagsvaerd, Denmark) } \\
\text { (repaglinide/metformin IR: } \\
\text { 1/500, 2/500; twice daily) }\end{array}$ & - & $\begin{array}{l}\text { Meglitinide } \\
\text { - Increases insulin secretion }\end{array}$ \\
\hline $\begin{array}{l}\text { Metformin + DPP-4 } \\
\text { inhibitor } \\
(\mathrm{A}, \mathrm{C})\end{array}$ & $\begin{array}{l}\text { Janumet }^{\circ} \text { (Merck \& Co., NJ, USA) } \\
\text { (sitagliptin/metformin IR: } \\
\text { 50/500, 50/1000; twice daily) } \\
\text { Kombiglyze XR (Bristol-Myers } \\
\text { Squibb, NJ, USA; AstraZeneca, } \\
\text { London, UK) } \\
\text { (saxagliptin/metformin XR: } \\
\text { 5/500, 5/1000, 2.5/1000; } \\
\text { once daily) }\end{array}$ & $\begin{array}{l}\text { Efficib }^{\circ} \text {,Janumet } \\
\text { Velmetia }{ }^{\circ} \text { (Merck \& } \& \text { Co., } \\
\text { NJ, USA) } \\
\text { Komboglyze }^{\bullet} \text { (Bristol- } \\
\text { Myers Squibb, NJ, } \\
\text { USA) }\end{array}$ & $\begin{array}{l}\text { DPP-4 inhibitor } \\
\text { - Blocks breakdown of } \\
\text { endogenous GLP-1 and GIP to } \\
\text { stimulate postprandial insulin } \\
\text { and suppress glucagon, in a } \\
\text { glucose-dependent manner }\end{array}$ \\
\hline \multirow[t]{3}{*}{$\begin{array}{l}\text { Metformin + TZD } \\
\text { (A) }\end{array}$} & $\begin{array}{l}\text { Actoplus } \text { Met }^{\circledast} \text { (Takeda } \\
\text { Pharmaceuticals, Osaka, Japan) } \\
\text { (pioglitazone/metformin IR: } \\
\text { 15/500,15/850; divided doses } \\
\text { with meals) }\end{array}$ & $\begin{array}{l}\text { Competact }^{\oplus} \\
\text { Glubrava }^{\circledR} \text { (Takeda } \\
\text { Pharmaceuticals, } \\
\text { Osaka, Japan) }\end{array}$ & $\begin{array}{l}\text { TZD } \\
\text { - Improves peripheral insulin } \\
\text { sensitivity and increases } \\
\text { glucose uptake in muscle and } \\
\text { fat }\end{array}$ \\
\hline & $\begin{array}{l}\text { Actoplus Met XR (Takeda } \\
\text { Pharmaceuticals, Osaka, Japan) } \\
\text { (pioglitazone/metformin XR: } \\
\text { 15/1000, 30/1000; once daily) }\end{array}$ & - & $\begin{array}{l}\text { - Improves hepatic insulin } \\
\text { sensitivity and reduces hepatic } \\
\text { glucose output }\end{array}$ \\
\hline & $\begin{array}{l}\text { Avandamet }^{\circ} \text { (GlaxoSmithKline } \\
\text { Plc, Brentford, UK) } \\
\text { (rosiglitazone/metformin IR: } \\
\text { 2/500, 4/500, 2/1000, 4/1000; } \\
\text { divided doses with meals) }\end{array}$ & - & \\
\hline
\end{tabular}


Table 1 (continued). Available fixed-dose combinations (FDCs) by class and mechanism of action.

\begin{tabular}{|c|c|c|c|}
\hline Class (targets*) & $\begin{array}{l}\text { US trade name(s) } \\
\text { (generic components: dose }[\mathrm{mg}] \text {; } \\
\text { frequency) }\end{array}$ & $\begin{array}{l}\text { Available in Europe } \\
\text { as: }\end{array}$ & Mechanisms of action \\
\hline \multirow[t]{2}{*}{$\begin{array}{l}\text { TZD + sulfonylurea } \\
(\mathrm{A}, \mathrm{B})\end{array}$} & $\begin{array}{l}\text { Avandaryl }{ }^{\circ}(\text { GlaxoSmithKline Plc, } \\
\text { Brentford, UK) } \\
\text { (rosiglitazone/glimepiride: } 4 / 1 \text {, } \\
4 / 2,4 / 4,8 / 2,8 / 4 \text {; once daily) }\end{array}$ & - & \\
\hline & $\begin{array}{l}\text { Duetact }^{\circ} \text { (Takeda Pharmaceuticals, } \\
\text { Osaka, Japan) } \\
\text { (pioglitazone/glimepiride: } 30 / 2 \text {, } \\
\text { 30/4; once daily) }\end{array}$ & $\begin{array}{l}\text { Tandemact }{ }^{\oplus} \text { (Takeda } \\
\text { Pharmaceuticals, } \\
\text { Osaka, Japan) }\end{array}$ & \\
\hline
\end{tabular}

*Targets: $A=$ insulin resistance; $B=$ impaired insulin secretion; $C=$ impaired incretin function.

DPP-4=dipeptidyl peptidase-4; FDC=fixed-dose combination; GIP=glucose-dependent insulinotropic polypeptide; GLP-1=glucagon-like peptide-1; IR=immediate-release formulation; TZD=thiazolidinedione; $\mathrm{XR}=$ extended-release formulation.

Using monotherapy to target a single defect is often inadequate to achieve glycemic goals, and the result is prolonged exposure to hyperglycemia and an increased risk of diabetic complications. ${ }^{11-14}$ Consequently, combination therapy using agents with complementary mechanisms of action has become a cornerstone of T2DM management.

The algorithm created for the American Diabetes Association and European Association for the Study of Diabetes recommends combination therapy for all patients with glycated hemoglobin (A1C) $>7 \%$ after 2-3 months of metformin monotherapy. ${ }^{15} \mathrm{An}$ algorithm created for the American Association of Clinical Endocrinologists and the American College of Endocrinology advises combination therapy when oral monotherapy fails to achieve or maintain A1C $\leq 6.5 \%$ after 2 -3 months and consideration of combination therapy at the time of diagnosis for patients with A1C $>7.5 \% .{ }^{16}$ However, both algorithms emphasize the importance of individualizing glycemic goals based on a number of factors, including duration of diabetes, life expectancy, history of significant hypoglycemia or hypoglycemia unawareness, and presence of extensive comorbid conditions or advanced diabetic complications, including cardiovascular disease.

Combination antihyperglycemic pharmacotherapy will eventually be necessary for the majority of patients with T2DM, owing to the progressive nature of the disease. ${ }^{15,16}$ Furthermore, because these patients often have hypertension, dyslipidemia, and other comorbidities that require pharmacotherapy, ${ }^{17}$ patients are likely to be taking multiple medications even before antihyperglycemic pharmacotherapy is initiated. Thus, polypharmacy is a frequent problem in this population, and the use of FDCs is a rational approach to achieving and maintaining glycemic control while minimizing what may already be a heavy pill-burden for the patient.

\section{USE OF FDCs IN T2DM}

To date, 10 FDCs have been approved for use in the treatment of T2DM in the USA (Table 1). Despite their utility and convenience, FDCs 
are used by only a minority of eligible patients. Some reports show that combination therapy using separate pills is 2-3 times more common than the use of FDCs. ${ }^{18,19}$ Among patients switching from monotherapy to combination therapy, the number who went to separate-pill combinations was $>4$ times greater than the number who went to FDCs ( $n=2518$ vs. $n=543)$; and among patients who were already on separatepill combination therapy, the number who stayed on dual therapy was $>46$ times greater than the number who switched to FDCs $(n=13,145$ vs. $n=284) .{ }^{20}$ In another report, $>17$ times more patients switched from monotherapy to combination therapy were prescribed dual therapy rather than FDCs $(n=1815$ vs. $n=105){ }^{21}$

There are several possible explanations for the relatively low use of FDCs. Prescribers may perceive difficulty in dose titration and adjustment, and in attributing adverse events to a specific component drug. Payers, managedcare organizations, and formulary managers may be concerned about costs. A survey of patients' attitudes about FDCs ${ }^{22}$ revealed concerns about pill size, lack of flexibility in dose timing, potential allergies, and marginal reduction in pill burden if they were taking numerous other medications for comorbid conditions. In addition, patients who are satisfied taking separate pills in combination may see no reason to change.

\section{ADDRESSING CONCERNS REGARDING THE USE OF FDCS FOR T2DM}

\section{Therapeutic Effectiveness}

Therapeutic effectiveness with FDCs is generally equivalent to combination therapy with their component drugs given as separate pills. As shown in Table 2, ${ }^{23-30}$ reductions in A1C and fasting glucose are greater with $\mathrm{FDCs}^{23-27}$ and with dual therapy ${ }^{28-30}$ than with monotherapy.

Some FDCs may offer an efficacy advantage over combination treatment with separate pills, although this has not been confirmed by prospective randomized trials. In a 2010 report by Thayer et al., a retrospective analysis of data from 16,490 managed-care patients with T2DM showed significant improvements in adherence $(P<0.001)$ and reductions in A1C $(P=0.004)$ in patients who switched from separate-pill combination therapy to an FDC versus those who continued on separate-pill regimens. ${ }^{20}$ Similarly, a retrospective study in 1421 patients showed significantly greater improvement in A1C with a metformin/glyburide FDC than with coadministration of separate pills, despite the fact that mean dosages were significantly lower with the FDC. Use of the FDC was also associated with significantly greater adherence, although there was no significant correlation between improved adherence and improved A1C. ${ }^{31}$

\section{Tolerability}

Tolerability is comparable with combination therapy delivered as an FDC or as separate pills because the dosage is often similar with both regimens (Table 3). ${ }^{23-30}$ The perception that it is difficult to attribute adverse effects to a particular component of an FDC may be valid in the case of initial combination therapy in a drug-naive patient, but that concern would also apply to dual therapy. For patients who have switched from monotherapy to dual therapy by adding a second drug, a switch from dual therapy to a comparable regimen delivered via an FDC would not be expected to cause new tolerability issues. 


\section{Dosing Flexibility}

The currently available FDCs for use in patients with T2DM are formulated in a variety of useful dosage combinations, as shown in Table 1. It should be kept in mind that dosing flexibility with individually administered drugs is limited to combinations reflecting the available formulations of each drug.

\section{Adherence}

Approximately $50 \%$ of patients with chronic diseases show poorer-than-expected responses to prescribed medication because of inadequate adherence, ${ }^{32}$ a problem that applies to patients with T2DM. ${ }^{33-35}$ In chronic, complex conditions in which polypharmacy is common, a reduction in pill burden could potentially enhance adherence, ${ }^{36}$ which may be achieved with FDCs. ${ }^{18,19,37-40}$

In a retrospective analysis of outcomes among more than 11,000 diabetic patients in a managed-care organization, nonadherence to oral antihyperglycemic medication (administered in $<80 \%$ of the total number of days covered by filled prescriptions) was associated with statistically significant $(P<0.001)$ increases in all-cause mortality and all-cause hospitalization; conversely, each $25 \%$ increase in adherence to antihyperglycemic medication was associated with a $0.05 \%$ decrease (95\% CI, -0.08 to -0.01 ) in A1C. ${ }^{35}$ Similarly, analyses of pharmacy claims

Table 2. Effects of combination versus monotherapy on glycemic parameters in patients with type 2 diabetes mellitus (T2DM) for two-drug regimens now available in fixed-dose combinations (FDCs) (continued on next page).

\begin{tabular}{|c|c|c|c|c|c|}
\hline \multirow[b]{2}{*}{ Treatment ${ }^{\text {reference }}$} & \multirow{2}{*}{$\begin{array}{l}\text { Maximum daily doses, } \mathrm{mg} \\
\text { (via titration as per protocol) }\end{array}$} & \multicolumn{2}{|l|}{ A1C, $\%$} & \multicolumn{2}{|c|}{$\begin{array}{l}\text { Fasting plasma } \\
\text { glucose, } \mathrm{mg} / \mathrm{dL}\end{array}$} \\
\hline & & Baseline & Change & Baseline & Change \\
\hline \multirow{5}{*}{$\begin{array}{l}\text { Glucovance }^{\circ} \\
\text { (metformin + glyburide) } \\
\text { 20-week study of initial FDC } \\
\text { therapy }^{23}\end{array}$} & \multirow{5}{*}{$\begin{array}{l}\text { MET } 1000 / \text { GLY } 5 \\
\text { MET } 2000 / \text { GLY } 10 \\
\text { MET } 2000 \\
\text { GLY } 10 \\
\text { Placebo }\end{array}$} & 8.25 & $-1.48^{*}$ & 177 & $-42 \dagger$ \\
\hline & & 8.18 & $-1.53^{*}$ & 175 & $-40 \dagger$ \\
\hline & & 8.26 & -1.03 & 176 & -21 \\
\hline & & 8.21 & -1.24 & 179 & -36 \\
\hline & & 8.21 & -0.21 & 177 & +5 \\
\hline Actoplus Met ${ }^{\circ}$ & \multirow{3}{*}{$\begin{array}{l}\text { PIO 30/MET } 1700 \\
\text { PIO } 30 \\
\text { MET } 1700\end{array}$} & 8.89 & $-1.83 \neq$ & 177.5 & $-39.9^{*}$ \\
\hline (pioglitazone + metformin) & & 8.69 & -0.96 & 170.8 & -22.2 \\
\hline $\begin{array}{l}\text { 24-week study of initial FDC } \\
\text { therapy }{ }^{24}\end{array}$ & & 8.65 & -0.99 & 170.5 & -24.8 \\
\hline Avandamet $^{\circ}$ & \multirow{3}{*}{$\begin{array}{l}\text { ROSI } 8 / \text { MET } 2000 \\
\text { ROSI } 8 \\
\text { MET } 2000\end{array}$} & \multirow{3}{*}{$\begin{array}{l}8.9 \\
8.8 \\
8.8\end{array}$} & \multirow{3}{*}{$\begin{array}{l}-2.3 \neq \\
-1.6 \\
-1.8\end{array}$} & \multirow{3}{*}{$\begin{array}{l}202 \\
193 \\
198\end{array}$} & \multirow{3}{*}{$\begin{array}{l}-74 \neq \\
-47 \\
-50\end{array}$} \\
\hline (rosiglitazone + metformin) & & & & & \\
\hline $\begin{array}{l}\text { 32-week study of initial FDC } \\
\text { therapy }{ }^{25}\end{array}$ & & & & & \\
\hline Avandaryl $^{\circ}$ & \multirow{4}{*}{$\begin{array}{l}\text { ROSI 4/GLIM } 4 \\
\text { ROSI 8/GLIM } 4 \\
\text { ROSI } 8 \\
\text { GLIM } 4\end{array}$} & \multirow{4}{*}{$\begin{array}{l}9.0 \\
9.2 \\
9.1 \\
9.0\end{array}$} & \multirow{4}{*}{$\begin{array}{l}-2.41 \neq \\
-2.52 \neq \\
-1.75 \\
-1.72\end{array}$} & \multirow{4}{*}{$\begin{array}{l}207 \\
214 \\
212 \\
211\end{array}$} & \multirow{4}{*}{$\begin{array}{l}-70 \neq \\
-80 \neq \\
-57 \\
-42\end{array}$} \\
\hline (rosiglitazone + glimepiride) & & & & & \\
\hline 28-week study of initial FDC & & & & & \\
\hline therapy ${ }^{26}$ & & & & & \\
\hline Metaglip & \multirow{3}{*}{$\begin{array}{l}\text { GLIP 20/MET } 2000 \\
\text { GLIP } 30 \\
\text { MET } 2000\end{array}$} & \multirow{3}{*}{$\begin{array}{l}8.7 \\
8.9 \\
8.7\end{array}$} & \multirow{3}{*}{$\begin{array}{l}-1.3 \S \\
-0.4 \\
-0.2\end{array}$} & \multirow{3}{*}{$\begin{array}{l}194 \\
204 \\
191\end{array}$} & \multirow{3}{*}{$\begin{array}{l}\text { NR@ } \\
\text { NR } \\
\text { NR }\end{array}$} \\
\hline (glipizide + metformin) & & & & & \\
\hline $\begin{array}{l}18 \text {-week study of initial FDC } \\
\text { therapy }{ }^{27}\end{array}$ & & & & & \\
\hline
\end{tabular}


Table 2 (continued). Effects of combination versus monotherapy on glycemic parameters in patients with type 2 diabetes mellitus (T2DM) for two-drug regimens now available in fixed-dose combinations (FDCs).

\begin{tabular}{|c|c|c|c|c|c|}
\hline \multirow[b]{2}{*}{ Treatment $\mathrm{t}^{\text {reference }}$} & \multirow{2}{*}{$\begin{array}{l}\text { Maximum daily doses, } \mathrm{mg} \\
\text { (via titration as per protocol) }\end{array}$} & \multicolumn{2}{|l|}{ A1C, $\%$} & \multicolumn{2}{|c|}{$\begin{array}{l}\text { Fasting plasma } \\
\text { glucose, } \mathrm{mg} / \mathrm{dL}\end{array}$} \\
\hline & & Baseline & Change & Baseline & Change \\
\hline Metformin + repaglinide & MET 1800||/REPAG 4 & 8.3 & -1.41 & 184 & -39.3 \\
\hline (now available as Prandimet ${ }^{\circ}$ ) & MET 1800\| & 8.6 & -0.33 & 195 & -4.5 \\
\hline $\begin{array}{l}\text { 16- to } 20 \text {-week study of repaglinide } \\
\text { added to ongoing metformin } \\
\text { (individual pills) })^{28}\end{array}$ & REPAG 4 & 8.6 & -0.38 & 174 & +8.6 \\
\hline \multirow{2}{*}{$\begin{array}{l}\text { Sitagliptin }+ \text { metformin } \\
\left.\text { (now available as Kombiglyze } \mathrm{XR}^{\oplus} \#\right)\end{array}$} & SAXA 5/MET 2000 & 9.4 & $-2.5^{* *}$ & 199 & $-60+\dagger$ \\
\hline & SAXA 10/MET 2000 & 9.5 & $-2.5^{* *}$ & 204 & $-62^{* *}$ \\
\hline \multirow{2}{*}{$\begin{array}{l}\text { 24-week study of initial dual } \\
\text { combination therapy (individual } \\
\text { pills) }{ }^{29}\end{array}$} & SAXA 10 & 9.6 & -1.7 & 201 & -31 \\
\hline & MET 2000 & 9.4 & -2.0 & 198 & -47 \\
\hline Sitagliptin + metformin & SITA 100/MET 1000 & 8.79 & $-1.40 \$$ & 203.9 & $-47.1 \S$ \\
\hline (now available as Janumet ${ }^{\circledR}$ ) & SITA 100/MET 2000 & 8.76 & $-1.90 \S$ & 196.7 & $-63.9 \S$ \\
\hline \multirow{4}{*}{$\begin{array}{l}\text { 24-week study of initial dual } \\
\text { combination therapy (individual } \\
\text { pills) }\end{array}$} & SITA 100 & 8.87 & -0.66 & 201.4 & -17.5 \\
\hline & MET 1000 & 8.90 & -0.82 & 205.2 & -27.3 \\
\hline & MET 2000 & 8.68 & -1.13 & 197.0 & -29.3 \\
\hline & Placebo & 8.68 & +0.17 & 196.3 & +5.8 \\
\hline
\end{tabular}

${ }^{*} P<0.01$ versus all monotherapies.

$+P \leq 0.001$ versus MET monotherapy.

$\neq P<0.0001$ versus all monotherapies.

$\S P \leq 0.001$ versus all monotherapies.

||Prestudy dosage of MET maintained. Mean daily MET dose presented.

g $P<0.05$ versus all monotherapies.

\#SAXA is not approved at $10 \mathrm{mg}$; Kombiglyze XR is available with SAXA $2.5 \mathrm{mg}$ plus MET $1000 \mathrm{mg}$ or with SAXA 5 mg plus MET 500 or $1000 \mathrm{mg}$.

${ }^{* *} P<0.0001$ versus MET monotherapy.

$\dagger+P=0.0002$ versus MET monotherapy.

A1C=glycated hemoglobin; GLIM=glimepiride; GLIP=glipizide; GLY=glyburide; $M E T=$ metformin; NR=value not reported; $\mathrm{PIO}=$ pioglitazone; $\mathrm{REPAG}=$ repaglinide; $\mathrm{ROSI}=$ rosiglitazone; $\mathrm{SAXA}=$ saxagliptin; $\mathrm{SITA}=$ sitagliptin; $\mathrm{XR}=$ extended-release formulation.

for patients with T2DM have revealed that a $10 \%$ poorer score on an adherence measure corresponds with a $0.14 \%$ increase in A1C. ${ }^{34}$

Among patients with T2DM using combination therapy, adherence tends to be greater with FDCs than with separate pills ${ }^{21,31}$ and greater after switching from monotherapy to an FDC rather than to separate-pill combinations. ${ }^{18,19,21}$ In the previously cited retrospective analysis by Thayer et al., adherence rates declined slightly among patients who were switched from monotherapy to combination therapy, but the decline was significantly smaller when switching to an FDC versus switching to separate-pill combinations. ${ }^{20}$ In contrast, among patients who were already using separate-pill combinations, adherence improved significantly when switching to an FDC.

Treatment adherence tends to improve with drug regimens that are simplified by reducing the number of pills ${ }^{41-43}$ and reducing dosing frequency. ${ }^{44,45}$ By definition, all FDCs result 
Table 3. Selected adverse events reported with fixed-dose combinations (FDCs) in patients with type 2 diabetes mellitus (T2DM).

\begin{tabular}{|c|c|c|c|c|c|c|}
\hline \multirow[b]{2}{*}{ Treatment ${ }^{\text {reference }}$} & \multirow[b]{2}{*}{$\begin{array}{l}\text { Maximum daily doses, } \mathrm{mg} \\
\text { (via titration as per protocol) }\end{array}$} & \multicolumn{5}{|c|}{ Incidence, \% } \\
\hline & & $\begin{array}{l}\text { Nausea/ } \\
\text { vomiting }\end{array}$ & Diarrhea & $\begin{array}{l}\text { Abdominal } \\
\text { pain }\end{array}$ & Headache & $\begin{array}{l}\text { Hypo- } \\
\text { glycemia* }\end{array}$ \\
\hline \multirow{5}{*}{$\begin{array}{l}\text { Glucovance }^{\infty} \\
\text { (metformin }+ \text { glyburide) } \\
\text { 20-week study of initial FDC } \\
\text { therapy }^{23}\end{array}$} & MET 1000/GLY 5 & 1.9 & 7.6 & 5.7 & NR & 5.1 \\
\hline & MET 2000/GLY 10 & 4.9 & 12.3 & 5.6 & NR & 16.0 \\
\hline & MET 2000 & 6.3 & 15.1 & 5.0 & NR & 0 \\
\hline & GLY 10 & 0.6 & 4.4 & 3.1 & NR & 6.3 \\
\hline & Placebo & 4.3 & 3.1 & 1.9 & NR & 0.6 \\
\hline \multirow{3}{*}{$\begin{array}{l}\text { Actoplus Met } \\
\text { (pioglitazone }+ \text { metformin) } \\
\text { 24-week study of initial FDC } \\
\text { therapy }^{24}\end{array}$} & PIO 30/MET 1700 & NR & 9.0 & 2.0 & 5.5 & 1.0 \\
\hline & PIO 30 & NR & 2.6 & 1.6 & 2.6 & 0.5 \\
\hline & MET 1700 & NR & 15.3 & 3.3 & 4.8 & 1.4 \\
\hline \multirow{3}{*}{$\begin{array}{l}\text { Avandamet }^{\circ} \\
\text { (rosiglitazone }+ \text { metformin) } \\
\text { 32-week study of initial FDC } \\
\text { therapy }^{25}\end{array}$} & ROSI 8/MET 2000 & 16 & 14 & NR & 11 & 0.6 \\
\hline & ROSI 8 & 8 & 7 & NR & 10 & 0 \\
\hline & MET 2000 & 13 & 21 & NR & 12 & 1.3 \\
\hline \multirow{4}{*}{$\begin{array}{l}\text { Avandaryl }^{-} \\
\text {(rosiglitazone + glimepiride) } \\
\text { 28-week study of initial FDC } \\
\text { therapy }^{26}\end{array}$} & ROSI 4/GLIM 4 & NR & NR & NR & $\sim 4.4$ & 3.6 \\
\hline & ROSI 8/GLIM 4 & NR & NR & NR & across & 5.5 \\
\hline & ROSI 8 & NR & NR & NR & groups & 0.4 \\
\hline & GLIM 4 & NR & NR & NR & & 4.1 \\
\hline \multirow{3}{*}{$\begin{array}{l}\text { Metaglip } \\
\text { (glipizide }+ \text { metformin) } \\
\text { 18-week study of initial FDC } \\
\text { therapy }^{27}\end{array}$} & GLIP 20/MET 2000 & 8.0 & 18.4 & 5.7 & 12.6 & 12.6 \\
\hline & GLIP 30 & 6.0 & 13.1 & 8.3 & 6.0 & 0 \\
\hline & MET 2000 & 8.0 & 17.3 & 6.7 & 5.3 & 1.3 \\
\hline \multirow{3}{*}{$\begin{array}{l}\text { Metformin + repaglinide } \\
\text { (now available as Prandimet }^{\circ} \text { ) } \\
16 \text { - to } 20 \text {-week study of } \\
\text { repaglinide added to ongoing } \\
\text { metformin (individual pills) }\end{array}$} & MET $\sim 1800 \dagger /$ REPAG 4 & NR & 18.5 & NR & 22.2 & 4.9 \\
\hline & MET 1800† & NR & 29.6 & NR & 14.8 & all groups \\
\hline & REPAG 4 & NR & 7.1 & NR & 10.7 & combined \\
\hline \multirow{4}{*}{$\begin{array}{l}\text { Saxagliptin }+ \text { metformin } \\
\text { (now available as Kombiglyze XR } \neq \text { ) } \\
\text { 24-week study of initial dual } \\
\text { therapy (individual pills) }\end{array}$} & SAXA 5/MET 2000 & NR & 6.9 & NR & 7.5 & 0.0 \\
\hline & SAXA 10/MET 2000 & NR & 9.6 & NR & 9.9 & 0.6 \\
\hline & SAXA 10 & NR & 3.0 & NR & 6.3 & 0.0 \\
\hline & MET 2000 & NR & 7.3 & NR & 5.2 & 0.3 \\
\hline \multirow{2}{*}{$\begin{array}{l}\text { Sitagliptin }+ \text { metformin } \\
\text { (now available as Janumet }^{\circledR} \text { ) }\end{array}$} & SITA 100/MET 1000 & 5.3 & 6.3 & 2.6 & NR & 1.1 \\
\hline & SITA 100/MET 2000 & 8.8 & 8.8 & 3.3 & NR & 2.2 \\
\hline \multirow{4}{*}{$\begin{array}{l}\text { 24-week study of initial dual } \\
\text { therapy (individual pills) }{ }^{30}\end{array}$} & SITA 100 & 1.1 & 2.8 & 3.4 & NR & 0.6 \\
\hline & MET 1000 & 2.7 & 4.9 & 2.7 & NR & 0.5 \\
\hline & MET 2000 & 9.3 & 10.4 & 4.9 & NR & 1.1 \\
\hline & Placebo & 1.7 & 4.0 & 2.3 & NR & 0.6 \\
\hline
\end{tabular}

${ }^{*}$ Defined as symptoms and blood glucose $\leq 50 \mathrm{mg} / \mathrm{dL}$ in the studies of MET/GLY, GLIP/MET, MET/REPAG, and SAXA/ MET, as symptoms and/or blood glucose $<60 \mathrm{mg} / \mathrm{dL}$ in the study of PIO/MET, and as "events" in the study of SITA/MET. †Prestudy dosage of MET maintained. Mean daily MET dose presented.

キSAXA is not approved at $10 \mathrm{mg}$; Kombiglyze XR is available with SAXA $2.5 \mathrm{mg}$ plus MET $1000 \mathrm{mg}$ or with SAXA 5 mg plus MET 500 or $1000 \mathrm{mg}$.

GLIM=glimepiride; GLIP=glipizide; GLY=glyburide; $M E T=$ metformin; NR=value not reported; $\mathrm{PIO}=$ pioglitazone; $\mathrm{REPAG}=$ repaglinide; $\mathrm{ROSI}=$ rosiglitazone; SAXA=saxagliptin; SITA=sitagliptin; $\mathrm{XR}=$ extended-release formulation. 
in reduced numbers of pills compared with the equivalent combination of separate pills. Older FDCs containing immediate-release metformin require twice-daily dosing to ensure adequate plasma levels of metformin; ;-6,10 whilst newer FDCs (pioglitazone plus extendedrelease metformin, ${ }^{6}$ saxagliptin plus extendedrelease metformin, ${ }^{9}$ and a TZD [rosiglitazone or pioglitazone] plus glimepiride ${ }^{7,8}$ ) can be administered once daily.

\section{Cost-Effectiveness}

The estimated total of direct and indirect costs of diabetes in the USA was $\$ 174$ billion in 2007 (most recent data available). ${ }^{46}$ In a systematic review, inadequate adherence to treatment for diabetes was linked to more healthcare utilization and higher costs (although the review also revealed wide methodologic variability among cost-effectiveness studies). ${ }^{47}$ Conversely, improved adherence has been associated with lower costs in treating dyslipidemia. ${ }^{38}$ Thus, because FDCs for T2DM can facilitate adherence and thereby reduce the long-term risk of complications and emergencies requiring hospitalization, they have the potential to reduce overall expenditures for patients with T2DM.

In terms of the cost of the medications, an analysis of Texas Medicaid payments showed that branded FDCs were significantly $(P<0.001)$ less expensive than regimens consisting of the branded component medications taken separately. ${ }^{19}$ It should be noted, however, that a branded FDC would almost certainly be more expensive than generics taken as separate pills. Similarly, in hypertension, prescription costs for FDCs versus the component drugs obtained separately were higher with respect to patients' out-of-pocket expenses, but lower with respect to total expenses paid by governmental or private third-party payers. ${ }^{48}$
Another report in hypertension showed reduced overall medical expenditures associated with use of an FDC, largely owing to decreased hospitalization. ${ }^{49}$ In addition, among hypertensive patients being treated with FDCs, adherence was greater and costs were lower with continued use of FDCs rather than with switching to separate-pill combinations. ${ }^{50}$

\section{CONCLUSION}

Because regulatory approval of FDCs is based on bioavailability data, similar to the way generic medications are approved, the lack of prospective, randomized controlled trials directly comparing FDCs with their component drugs administered as separate pills should not be considered a limitation to their use. Although the studies reviewed here are of relatively short duration, there is no reason to believe that the effects of long-term treatment with FDCs would differ from the effects of long-term dual therapy with their component drugs given as separate pills for the treatment of T2DM, as has previously been reported in peer-reviewed literature. An area where more research is needed involves the direct comparison of drug acquisition costs and total treatment costs with brand-name FDCs versus component drugs given as separately administered generics, as the currently available data are limited.

The purpose of this review was to address any false perceptions on the part of physicians, patients, or payers that may affect utilization of FDCs for the treatment of T2DM. Based on the authors' review of the published literature, it is apparent that FDCs offer several advantages over combination therapy delivered by separate pills. For therapeutic effectiveness and tolerability, FDCs are at least equal to the same medications when taken separately. In addition, FDCs are available 
in different dosage strength formulations, which allows for flexibility in selecting and adjusting dosages. Finally, greater convenience (decreased pill burden and, for some FDCs, once-daily dosing) may lead to improved adherence, which may yield superior clinical outcomes and greater cost-effectiveness.

\section{ACKNOWLEDGMENTS}

Dr Blonde has received grant/research support from Boehringer Ingelheim Pharmaceuticals, Inc., Eli Lilly and Company, Johnson \& Johnson, Novo Nordisk, Roche, and sanofiaventis; speaker honoraria from AstraZeneca, Boehringer Ingelheim Pharmaceuticals, Inc., Bristol-Myers Squibb, Daiichi Sankyo, Merck \& Co., Inc., Novo Nordisk, Santarus, and VeroScience; honoraria as a consultant to Amylin Pharmaceuticals, Inc., AstraZeneca, Boehringer Ingelheim Pharmaceuticals, Inc., Bristol-Myers Squibb, Daiichi Sankyo, GlaxoSmithKline, Halozyme, Johnson \& Johnson, Mannkind Corporation, Merck \& Co., Inc., Novo Nordisk, Orexigen Therapeutics, Roche, sanofi-aventis, Santarus, and VeroScience. Dr Blonde's late spouse's estate contains shares of Amylin Pharmaceuticals and Pfizer, Inc. Dr San Juan has no conflicts of interest to disclose.

The authors thank Gina Coviello, MS, and Diane Kwiatkoski, PhD (Quintiles Medical Communications, Parsippany, NJ, USA), and Steven Tiger, PA, and Erica S. Wehner, RPh, CMPP (Complete Healthcare Communications, Inc., Chadds Ford, PA, USA) for medical writing support funded by Bristol-Myers Squibb (Princeton, NJ, USA) and AstraZeneca LP (Wilmington, DE, USA). Dr Blonde is the guarantor for this article, and takes responsibility for the integrity of the work as a whole.
Open Access. This article is distributed under the terms of the Creative Commons Attribution Noncommercial License which permits any noncommercial use, distribution, and reproduction in any medium, provided the original author(s) and source are credited.

\section{REFERENCES}

1. Moulding T, Dutt AK, Reichman LB. Fixed-dose combinations of antituberculous medications to prevent drug resistance. Ann Intern Med. 1995;122:951-954.

2. METAGLIP $^{\circledR} \quad$ (glipizide and metformin hydrochloride). Full prescribing information, Bristol-Myers Squibb, Princeton, NJ. 2009. Available at: http://www.accessdata.fda.gov/ drugsatfda_docs/label/2008/021460s007lbl.pdf. Accessed December 23, 2011.

3. PRANDIMET $^{\circledR}$ (repaglinide and metformin hydrochloride). Full prescribing information, Novo Nordisk, Princeton, NJ. 2010. Available at: http://www.novo-pi.com/prandimet.pdf. Accessed December 23, 2011.

4. AVANDAMET $^{\circledR}$ (rosiglitazone and metformin hydrochloride). Full prescribing information, GlaxoSmithKline, Research Triangle Park, NC. 2008. Available at: http://us.gsk.com/products/assets/us avandamet.pdf. Accessed December 23, 2011.

5. JANUMET $^{\circledR}$ (sitagliptin and metformin hydrochloride). Full prescribing information, Merck \& Co, Whitehouse Station, NJ. 2010. Available at: http://www.merck.com/product/usa/ pi_circulars/j/janumet/janumet_pi.pdf. Accessed December 23, 2011.

6. ACTOPLUS MET ${ }^{\circledR}$ (pioglitazone hydrochloride and metformin hydrochloride) and ACTOPLUS MET $\mathrm{XR}^{\circledR} \quad$ (pioglitazone hydrochloride and metformin hydrochloride extended-release). Full prescribing information, Takeda Pharmaceuticals America, Inc., Deerfield, IL, 2010. Available at: http://general.takedapharm.com/content/file/ pi.pdf?applicationcode $=8$ a9c4571-a123-447791de-b9cafe7d07e3\&filetypecode=ACTOPLUSMET PI; http://general.takedapharm.com/content/file/ pi.pdf?applicationcode=8a9c4571-a123-4477-91deb9cafe7d07e3\&filetypecode=ACTOPLUSMETXRPI. Accessed December 23, 2011. 
7. AVANDARYL $^{\circledR}$ (rosiglitazone and glimepiride). Full prescribing information, GlaxoSmithKline, Research Triangle Park, NC. 2009. Available at: http://us.gsk.com/products/assets/us_avandaryl. pdf. Accessed December 23, 2011.

8. DUETACT ${ }^{\circledR}$ (pioglitazone and glimepiride). Full prescribing information, Takeda Pharmaceuticals America, Deerfield, IL. 2010. Available at: http:// www.accessdata.fda.gov/drugsatfda_docs/ label/2011/021925s010s011lbl.pdf. Accessed December 23, 2011.

9. KOMBIGLYZE $\mathrm{XR}^{\circledR}$ (saxagliptin and extendedrelease metformin hydrochloride). Full prescribing information, Bristol-Myers Squibb, Princeton, NJ. 2010. Available at: http://packageinserts.bms.com/ pi/pi_kombiglyze_xr.pdf. Accessed December 23, 2011.

10. GLUCOVANCE ${ }^{\circledR}$ (glyburide and metformin hydrochloride). Full prescribing information, Bristol-Myers Squibb, Princeton, NJ. 2010. Available at: http://www.accessdata.fda.gov/ drugsatfda_docs/label/2010/021178s012lbl.pdf. Accessed December 23, 2011.

11. Defronzo RA. Banting Lecture. From the triumvirate to the ominous octet: a new paradigm for the treatment of type 2 diabetes mellitus. Diabetes. 2009;58:773-795.

12. Turner RC, Cull CA, Frighi V, Holman RR. Glycemic control with diet, sulfonylurea, metformin, or insulin in patients with type 2 diabetes mellitus: progressive requirement for multiple therapies (UKPDS 49). UK Prospective Diabetes Study (UKPDS) Group. JAMA. 1999;281:2005-2012.

13. Brown JB, Nichols GA, Perry A. The burden of treatment failure in type 2 diabetes. Diabetes Care. 2004;27:1535-1540.

14. Riedel AA, Heien H, Wogen J, Plauschinat CA. Loss of glycemic control in patients with type 2 diabetes mellitus who were receiving initial metformin, sulfonylurea, or thiazolidinedione monotherapy. Pharmacotherapy. 2007;27:1102-1110.

15. Nathan DM, Buse JB, Davidson MB, et al. Medical management of hyperglycemia in type 2 diabetes: a consensus algorithm for the initiation and adjustment of therapy: a consensus statement of the American Diabetes Association and the European Association for the Study of Diabetes. Diabetes Care. 2009;32:193-203.
16. Rodbard HW, Jellinger PS, Davidson JA, et al. Statement by an American Association of Clinical Endocrinologists/American College of Endocrinology consensus panel on type 2 diabetes mellitus: an algorithm for glycemic control. Endocr Pract. 2009;15:540-559.

17. Hollander PA, Kushner P. Type 2 diabetes comorbidities and treatment challenges: rationale for DPP-4 inhibitors. Postgrad Med. 2010;122:7180 .

18. Pan F, Chernew ME, Fendrick AM. Impact of fixed-dose combination drugs on adherence to prescription medications. J Gen Intern Med. 2008;23:611-614.

19. Cheong C, Barner JC, Lawson KA, Johnsrud MT. Patient adherence and reimbursement amount for antidiabetic fixed-dose combination products compared with dual therapy among Texas Medicaid recipients. Clin Ther. 2008;30:18931907.

20. Thayer S, Arondekar B, Harley C, Darkow TE. Adherence to a fixed-dose combination of rosiglitazone/glimepiride in subjects switching from monotherapy or dual therapy with a thiazolidinedione and/or a sulfonylurea. Ann Pharmacother. 2010;44:791-799.

21. Melikian C, White TJ, Vanderplas A, Dezii CM, Chang E. Adherence to oral antidiabetic therapy in a managed care organization: a comparison of monotherapy, combination therapy, and fixeddose combination therapy. Clin Ther. 2002;24:460467.

22. Williams B, Shaw A, Durrant R, Crinson I, Pagliari C, de Lusignan S. Patient perspectives on multiple medications versus combined pills: a qualitative study. QJM. 2005;98:885-893.

23. Garber AJ, Larsen J, Schneider SH, Piper BA, Henry D. Simultaneous glyburide/metformin therapy is superior to component monotherapy as an initial pharmacological treatment for type 2 diabetes. Diabetes Obes Metab. 2002;4:201-208.

24. Perez A, Zhao Z, Jacks R, Spanheimer R. Efficacy and safety of pioglitazone/metformin fixed-dose combination therapy compared with pioglitazone and metformin monotherapy in treating patients with T2DM. Curr Med Res Opin. 2009;25:29152923. 
25. Rosenstock J, Rood J, Cobitz A, Biswas N, Chou $\mathrm{H}$, Garber A. Initial treatment with rosiglitazone/ metformin fixed-dose combination therapy compared with monotherapy with either rosiglitazone or metformin in patients with uncontrolled type 2 diabetes. Diabetes Obes Metab. 2006;8:650-660.

26. Chou HS, Palmer JP, Jones AR, et al. Initial treatment with fixed-dose combination rosiglitazone/glimepiride in patients with previously untreated type 2 diabetes. Diabetes Obes Metab. 2008;10:626-637.

27. Goldstein BJ, Pans M, Rubin CJ. Multicenter, randomized, double-masked, parallel-group assessment of simultaneous glipizide/metformin as second-line pharmacologic treatment for patients with type 2 diabetes mellitus that is inadequately controlled by a sulfonylurea. Clin Ther. 2003;25:890-903.

28. Moses R, Slobodniuk R, Boyages S, et al. Effect of repaglinide addition to metformin monotherapy on glycemic control in patients with type 2 diabetes. Diabetes Care. 1999;22:119-124.

29. Jadzinsky M, Pfutzner A, Paz-Pacheco E, Xu Z, Allen E, Chen R. Saxagliptin given in combination with metformin as initial therapy improves glycaemic control in patients with type 2 diabetes compared with either monotherapy: a randomized controlled trial. Diabetes Obes Metab. 2009;11:611-622.

30. Goldstein BJ, Feinglos MN, Lunceford JK, Johnson J, Williams-Herman DE. Effect of initial combination therapy with sitagliptin, a dipeptidyl peptidase- 4 inhibitor, and metformin on glycemic control in patients with type 2 diabetes. Diabetes Care. 2007;30:1979-1987.

31. Blonde L, Wogen J, Kreilick C, Seymour AA. Greater reductions in $\mathrm{A} 1 \mathrm{C}$ in type 2 diabetic patients new to therapy with glyburide/metformin tablets as compared to glyburide co-administered with metformin. Diabetes Obes Metab. 2003;5:424-431.

32. Gold DT, McClung B. Approaches to patient education: emphasizing the long-term value of compliance and persistence. Am J Med. 2006;119:S32-37.

33. Lawrence DB, Ragucci KR, Long LB, Parris BS, Helfer LA. Relationship of oral antihyperglycemic (sulfonylurea or metformin) medication adherence and hemoglobin A1C goal attainment for HMO patients enrolled in a diabetes disease management program. J Manag Care Pharm. 2006;12:466-471.
34. Pladevall M, Williams LK, Potts LA, Divine G, Xi $\mathrm{H}$, Lafata JE. Clinical outcomes and adherence to medications measured by claims data in patients with diabetes. Diabetes Care. 2004;27:2800-2805.

35. Ho PM, Rumsfeld JS, Masoudi FA, et al. Effect of medication nonadherence on hospitalization and mortality among patients with diabetes mellitus. Arch Intern Med. 2006;166:1836-1841.

36. Saleh SS, Szebenyi S, Carter JA, Zacher C, Belletti D. Patterns and associated health services costs of antihypertensive drug modifications. J Clin Hypertens (Greenwich). 2008;10:43-50.

37. Gerbino PP, Shoheiber O. Adherence patterns among patients treated with fixed-dose combination versus separate antihypertensive agents. Am J Health Syst Pharm. 2007;64:1279-1283.

38. Balu S, Simko RJ, Quimbo RM, Cziraky MJ. Impact of fixed-dose and multi-pill combination dyslipidemia therapies on medication adherence and the economic burden of sub-optimal adherence. Curr Med Res Opin. 2009;25:2765-2775.

39. Bangalore S, Kamalakkannan G, Parkar S, Messerli FH. Fixed-dose combinations improve medication compliance: a meta-analysis. Am J Med. 2007;120:713-719.

40. Brixner DI, Jackson KC 2nd, Sheng X, Nelson RE, Keskinaslan A. Assessment of adherence, persistence, and costs among valsartan and hydrochlorothiazide retrospective cohorts in freeand fixed-dose combinations. Curr Med Res Opin. 2008;24:2597-2607.

41. Dailey G, Kim MS, Lian JF. Patient compliance and persistence with antihyperglycemic drug regimens: evaluation of a Medicaid patient population with type 2 diabetes mellitus. Clin Ther. 2001;23:13111320.

42. Dailey G, Kim MS, Lian JF. Patient compliance and persistence with anti-hyperglycemic therapy: evaluation of a population of type 2 diabetic patients. J Int Med Res. 2002;30:71-79.

43. Donnan PT, MacDonald TM, Morris AD. Adherence to prescribed oral hypoglycaemic medication in a population of patients with type 2 diabetes: a retrospective cohort study. Diabet Med. 2002;19:279-284.

44. Guillausseau PJ. Influence of oral antidiabetic drugs compliance on metabolic control in type 2 diabetes. A survey in general practice. Diabetes Metab. 2003;29:79-81. 
45. Paes AH, Bakker A, Soe-Agnie CJ. Impact of dosage frequency on patient compliance. Diabetes Care. 1997;20:1512-1517.

46. National Diabetes Information Clearinghouse. National Diabetes Statistics, 2007. Bethesda, MD: National Institute of Diabetes and Digestive and Kidney Diseases, US Department of Health and Human Services, National Institutes of Health; 2008. NIH Publication No. 08-3892.

47. Salas M, Hughes D, Zuluaga A, Vardeva K, Lebmeier M. Costs of medication nonadherence in patients with diabetes mellitus: a systematic review and critical analysis of the literature. Value Health. 2009;12:915-922.
48. Rabbani A, Alexander GC. Out-of-pocket and total costs of fixed-dose combination antihypertensives and their components. Am J Hypertens. 2008;21:509-513.

49. Angus DC, Linde-Zwirble WT, Tam SW, et al. Cost-effectiveness of fixed-dose combination of isosorbide dinitrate and hydralazine therapy for blacks with heart failure. Circulation. 2005;112:3745-3753.

50. Hess G, Hill J, Lau H, Dastani H, Chaudhari P. Medication utilization patterns and hypertensionrelated expenditures among patients who were switched from fixed-dose to free-combination antihypertensive therapy. P T. 2008;33:652-666. 